\title{
PROBLEMS OF INFLATION, UNEMPLOYMENT AND INCOME DISTRIBUTION IN THE TRANSITION OF EASTERN BLOC COUNTRIES TO MARKET ECONOMY: EXAMPLES FROM SELECTED REGIONAL COUNTRIES \\ DOĞU BLOĞU ÜLKELERINIIN PIYYASA EKONOMISINNE GEÇISS SÜRECINDE ENFLASYON, İŞSİZLIK VE GELİR DAĞILIMI SORUNLARI: BÖLGESEL SEÇILMİŞ ÜLKE ÖRNEKLERI
}

Remzi BULUT ${ }^{1}$
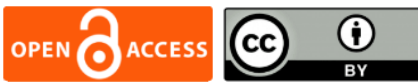

1. Dr. Öğr. Üyesi, Burdur Mehmet Akif Ersoy Üniversitesi, İktisadi ve İdari Bilimler Fakültesi, rbulut@mehmetakif.edu.tr, https://orcid.org/0000-0003-1169-2949

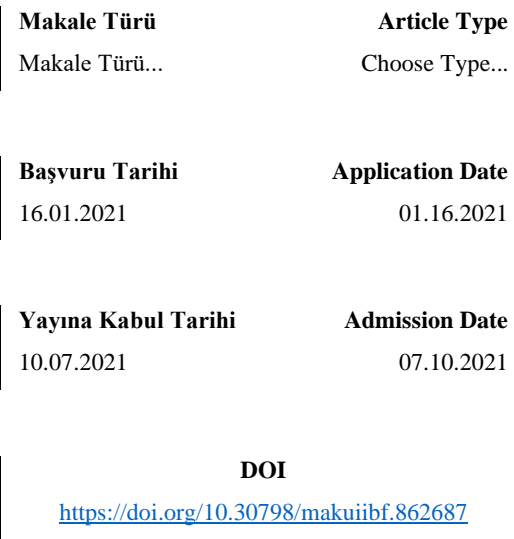

\begin{abstract}
The Eastern bloc fell with the unification of Germany and the fall of Soviet Union, Czechoslovakia and Yugoslavia. After the year 1991, the countries that consisted the old Eastern Bloc went in a pursuit of a new economical and political system. Generally, all of the transiting countries have adopted a transition towards a market economy. Because of this reason, the ex Eastern Bloc countries are also known as "Transition Countries" or "Transition Economies". These countries have started the reforms of transition to a market economy after the first years of the disbanding of the Eastern Bloc. With the beginning of the reforms, macro economical problems rose due to the change of systems. The most important of these problems are; inflation, unemployment and injustices in income distribution. In this work, theoretical information is provided about transition economies, transition periods and transition reforms. Besides, the problems of income distribution, unemployment and inflation in the select transition countries are discussed. As a result of this study it was concluded that transition reforms have an impact on inflation and unemployment and unemployment and inflation have an impact on per capita income.
\end{abstract}

Keywords: Transition Economies, Eastern Bloc, Inflation, Unemployment, National Income.

$\ddot{\mathbf{O} z}$

Doğu Bloğu; Doğu ve Batı Almanya'nın birleşmesi, Çekoslovakya, Yugoslavya ve Sovyetler Birliği'nin dağılmasıyla yıkılmıştır. 1991 yılı sonrası eski Doğu Bloğunu oluşturan ülkeler yeni bir ekonomik ve politik sistem arayışına girmişlerdir. Genel olarak tüm geçiş ülkeleri piyasa ekonomisine geçişi benimsemişlerdir. Bu nedenle eski Doğu Bloğu ülkelerine, "Geçiş Ülkeleri” veya "Geçiş Ekonomileri” denilmektedir. Bu ülkeler daha ilk yıllarda piyasa ekonomisine geçiş reformlarına başlamışlardır. Reformların başlamasıyla sistem değişikliğinden kaynaklı makroekonomide sorunlar çıkmıştır. Bu sorunlardan en önemlileri ise; enflasyon, işsizlik ve gelir dağılımındaki adaletsizliklerdir. Bu çalışmada geçiş ekonomileri, geçiş süreçleri ve geçiş reformları hakkında teorik bilgiler verilmiştir. Ayrıca seçilmiş geçiş ülkelerindeki enflasyon, işsizlik ve gelir dağılımı sorunları ele alınmıştır. Çalışma sonucunda geçiş reformlarının enflasyon ve işsizlik üzerinde, enflasyon ve işsizliğin de kişi başına düşen gelir üzerinde etkisi olduğu sonucuna varılmıştır

Anahtar Kelimeler: Geçiş Ekonomileri, Doğu Bloku, Enflasyon, İşsizlik, Milli Gelir. 


\section{Çalışmanın Amacı}

\section{GENIŞLETILMIŞ ÖZET}

Doğu Bloğu ülkeler 1990'lı yıllarda ekonomik açıdan gelişmiş batılı ülkelerle rekabet edemez hale gelmiştir. Dolaysıyla sosyalist sistemde ekonomik ve sosyal sorunlar ortaya çıkmaya başlamıştır. Bu ülkeler merkezi planlama sisteminin sona ermesiyle 1991 yılı sonrası yeni sistem arayışına girmişlerdir. Tüm eski sosyalist ülkeler serbest piyasa ekonomik sistemi benimsemişlerdir. Merkezi planlı ekonomik sistemden serbest piyasa ekonomik sisteme geçmeye karar vermişlerdir. Çalışmanın amacı olarak, Doğu Blokunun dağılmasıyla piyasa ekonomisine geçiş reformları ve reformların bazı makroekonomik yapıya etkileri incelenmiştir.

\section{Araştırma Soruları}

Araştırmada piyasa ekonomisine geçiş yapan ülkelerde geçiş reformlarının makroekonomik göstergelere etkili midir sorusuna cevap aranmaktadır. Geçişin hangi yöntemle gerçekleşmesi sorusuna cevap aranmıştır. Geçiş reformlarının özellikle enflasyon, işsizlik ve gelir dağılımı üzerindeki etkileri incelenmektedir. Çalışmada reform uygulamalarının geçiş ülkelerinde ekonomik sorunlara nasıl çözüm sunduğu çalışılmıştır.

\section{Literatür Araştırması}

Piyasa ekonomisine geçiş reformlarının enflasyon ve işsizlik üzerine çalışma ve araştırmaları geçiş ülkelerinde farklılıklar göstermektedir. Çalışmalar genellikle ülke gruplarının incelenmesi veya piyasa ekonomisine geçiş reform uygulamalarının herhangi bir geçiş ülkesi örneği şeklinde yapılmıştır. Geçiş ülkeleri üzerine çalışmalar 2000'li yıllardan sonra ağırlık kazanmaktadır. Geçiş ekonomileri ile ilgili sınırlı sayıda kitap yayımlanmıştır. Yapılan araştırmalar genel olarak teorik yaklaşımlar üzerine kurulmuştur. Çalışmalar farklı ülke grupları veya karşılaştırmalı olarak ele alınmıştır. Literatür araştırmalarında kullanılan en önemli kavram reformların uygulanması ve piyasa ekonomisine geçiş kavramıdır. Vurgulanan en önemli tema ise merkezi planlama sisteminden serbest piyasa ekonomisine geçiştir. Çalışmaların çoğunluğunda geçiş reform uygulamalarının makroekonomik sorunların çözümüne pozitif yönde etki yaptı̆̆ bulunmuştur. Merkezi sistem ile yönetilen ülkelerin serbest piyasa ekonomisine geçişiyle literatüre "geçiş ülkeleri” ve "geçiş ekonomileri” alanları girmiştir. Geçiş ülkeleri kavramı ile geçiş ekonomileri kavramı arasında herhangi bir farkın olmadığı iktisatçılar tarafından kabul edilmektedir.

\section{Yöntem}

Çalışma teorik olarak yapılmıştır. Bazı geçiş ülkelerinin 1991 - 2019 yılları arası enflasyon, işsizlik ve kişi başı milli gelir verileri tablo haline getirilerek yorumlanmıştır. Reform uygulamalarının veriler üzerine etkileri yorumlanarak tartışılmıştır. Grafik olarak ülke gruplarının ortalaması ele alınarak gelişim durumları analiz edilmiştir. Bazı geçiş ülkelerinin verilerine ulaşılamadığından dolayı sağlıklı veri analiz çalışmasının yapılamayacağı düşünülmüştür. Yine her bir geçiş ülkesinin istatistiki verileri 
ile dünya bankası verilerinin farklı oluşu analiz yapılmasını sorunlu kılacağı düşüncesi hâkim olmuştur.

Bundan dolayı teorik bilgilerle yorumlanması daha sağlıklı olacağı düşünülmüştür.

\section{Sonuç ve Değerlendirme}

Araştırma bulgularına göre geçiş ülkelerinde reform uygulamalarının makroekonomik göstergeler üzerinde pozitif bir etkisi olduğu bulunmuştur. Bir başka anlatımla geçiş reform uygulamalarında başarılı olan ülkelerde hoşnutsuzluk oranlarının azaldığı, gelir ve refah seviyelerinin yükseldiği görülmüştür. Yaklaşık 70 yıllık merkezi planlama sisteminin sona ermesiyle eski Doğu bloku ülke ekonomileri yeniden şekillenmeye başlamıştır. Günümüzde geçiş ekonomileri veya ülkeleri olarak kabul edilen toplam 33 ülke bulunmaktadır. Bu ülkelerden Orta ve Doğu Avrupa' da bulunanlar ve Baltık ülkeleri sosyalist sistemde yaklaşık 40 ila 50 yıl süresince kalmışlardır. Kafkasya ve Orta Asya'da bulunan ülkeler 70 yıl sistem içinde kalmıştır. Nitekim daha az sosyalist sistemde kalan ülkeler piyasa ekonomisine geçiş reformlarını daha hızlı şekilde tamamlamışlardır. Uzun süre kalan ülkelerde hala geçiş reformları tamamlanamamıştır. Uzak Doğu Asya'da bulunan ülkeler daha farklı geçiş reformu uygulamaktadır. Hatta bu ülkeler sosyalist piyasa ülkeleri olarak da tanımlanmaktadır. Merkezi planlamadan serbest piyasa ekonomisine geçiş son derce karışık şekilde ilerlemektedir. Geçiş sürecinin ilk aşamasında tüm sosyalist ülkelerin makroekonomik yapılarında sorunlar yaşanmıştır. Geçiş sürecinde ülkelerin daha fazla sosyal ve ekonomik sorunlarla karşı karşıya kalınmaması için özel geçiş stratejisi ve politikalara ihtiyaç duyulmuştur. Çalışmada sınırlı makroekonomik sorunlar ve seçilmiş bazı ülkeler ele alınmıştır. Sorunların geneli ve geçiş ülkelerinin tümü düşünüldügünde daha farklı sonuçların çıkması muhtemeldir. Şöyle ki, Avrupa'ya yakın ülkelerin gelişmiş Avrupa ülkelerine, eski SSCB ülkelerinin çoğunluğunun Rusya Federasyonu'na ve Asya'da bulunan geçiş ülkelerin ise Çin Halk Cumhuriyeti'ne bağımlılıklarından söz edilebilir. Makroekonomik göstergelerdeki veri ve oranlarda benzerlikler görülmektedir. Piyasa ekonomisine geçişin ilk yıllarında fiyatlardaki liberalizasyon hızlı enflasyon döneminin yaşanmasına neden olmuştur. 1991 - 1993 yıllarında bazı geçiş ülkelerinde aylık \%30 enflasyon oranlarıyla yüksek ve hiperenflasyon olguları yaşanmıştır. Mal ve hizmet fiyatlarındaki ve ücretlerdeki artış aynı oranda olmamıştır. Dolaylı olarak da gelişmiş ülkelere işgücü ve beyin göçü hızlanmıştır. 1995 yılından sonra yabancı yatırımcı sayılarındaki artıştan ve IMF'den sağlanan krediler sayesinde enflasyon oranlarında düşüşler yaşanmaya başlamıştır. 1997 yılındaki Asya Mali Krizi Rusya Federasyonu ve komşu ülke ekonomilerini olumsuz yönde etkilemiştir. Serbest piyasa ekonomisine geçiş sürecinde uygulamaya konulan geçiş reform ve programları geçiş ülkeleri ekonomilerinde ilk etapta olumsuz etki meydana getirmiştir. Zaman ilerledikçe reformların uygulanmasıyla geçiş ülkeleri ekonomilerindeki sorunlar ortadan kalkmıştır. Doğu Avrupa geçiş ülkeleri kısa sürede enflasyon, işsizlik, kişi başına düşen milli gelir ve diğer makroekonomik sorunları çözüme kavuşturmuştur. 


\section{INTRODUCTION}

Eastern Bloc countries have become unable to compete with the economically developed Western countries. Economical and social problems began to surface within the system. The policies of Mikhail Gorbachev, who came to power in the USSR in the year 1985, namely, "Perestroika" (Restructuring) and Glasnost (Transparency) have laid the foundation for the collapse of the bloc. The unification of East and West Germany has also precipitated the dissolution of the Eastern Bloc. With the coup attempt in the Soviet Union on August 1991 and the dissolution of the USSR, an economical reform programmer was announced in the former Eastern Bloc countries (Bulut, 2014). The end of the nearly 70-year-old system also marked the beginning of the transition to a market economy.

A transition from centrally planned economical system to a market economy system first began in Poland during the end of the 1980's via swift and radical decisions. During the same period, it is held that the transition reforms to a market economy gradually began in Hungary as well. In January 1990, historical and important decisions have been arrived to, at the meeting of the Council for Mutual Economic Assistance (COMECON), which was held in in Sofia. According to the most important decision taken at the meeting, the conduct of trade with a strong unit of money and based on world economical prices has ended the economically interconnected Eastern Bloc (Çokünlü, 2007: 8).

After 1991, the countries that made up the Eastern Bloc sought a new system and adopted the transition to a market economy. Because of this reason, the ex-Eastern Bloc countries are also known as "Transition Countries" or "Transition Economies". Here, "Transition" is used as a concept in the meaning of "transformation" and "change". Transition economies are also interpreted in the economic literature as transiting from one style of production to another (Karış and Özyurt, 2015). Transition economies are also defined as the economies of countries that transit from a centrally planned economic system to a free market economy.

Another reason why the countries which were included in the old socialist system are called "transition economies" is that those countries in question are excluded from the categories of underdeveloped or developing countries in an economical and political sense (Sakınç, 2005). It is possible to evaluate some Central Asian republics within the scope of transition economies as economically and politically underdeveloped countries. Again, some countries in Eastern Europe and the Baltic can be evaluated in the category of developed countries in terms of economic and political potential.

The process of change of centrally planned economies began when state-controlled economies lost their function. Over time, capitalist market economies and institutions have replaced the gap that arose because of this. During the transition period, social and economic reforms began to be implemented. The most important common feature of the Eastern Bloc countries which are going 
through a transition period is that the political structure and organizations of these countries came to power in that very period (Karış and Özyurt, 2015).

Transition countries are located in different geographies and regions. There are some differences in the implementation of market economy transition reforms. Therefore, in the first years of the transition, there were problems in macroeconomic structures of the transition countries. The most important of these problems are inflation, unemployment and income distribution. These problems are recognized as a common problem of all transition countries going through the first years of transition (Bulut, 2020).

The aim of the study is to address the problems of inflation, unemployment and income distribution among the economic problems experienced by some select countries in the socialist system that are transitioning to a market economy. This study also provided theoretical information about the transition process to market economy and the reforms which are implemented through this process. The countries were selected according to geographical regions. The past and present data of inflation, unemployment and income distribution per capita of the countries which are transitioning to a market economy have been studied and interpreted.

\section{LITERATURE RESEARCH}

The inflation and unemployment studies and research of transition reforms vary by country. Studies have often taken a form of a research of the select country groups or an example of market economy transition reforms based on any country in question. Below are some studies made in the literature which examines the relationship between inflation, unemployment and other macroeconomic problems of transition reforms in countries with a transition economy?

Falcetti et al. (2000) analyzed the economies of 25 transition countries, covering the period from 1989 to 1998. The analysis found that the problem of inflation had negative effects on GDP and economic growth. Altayli et al. 2011) examined the G8 countries in their studies and found that there is a co-integration between inflation and the unemployment rate. In their studies, they found that there is a causal relationship from inflation to unemployment in the short term and from unemployment to inflation in the long term.

In his research, Janstsan (2013) argues that shock therapy in transition is results in an ironic finding, and that the phased approach attracts more investment. It is argued that the reform strategy and policy packages that need to be developed for transition economies should be considered within the framework of the institutional approach.

In her research, Aksel (2019) noted that countries which are close to developed European countries are implementing transition reforms to a market economy faster. He emphasized that these 
countries are solving macroeconomic problems more quickly than inflation and unemployment problems.

\section{TRANSITION COUNTRIES AND TRANSITION PROCESS}

\subsection{Transition Countries}

Transition countries consist of two parts. The first part of them is that the countries that make up the union or a bloc are states that are separated from the Union and the system and thus independent. Second, it has been in the form of those who were previously independent states but left the system. It is possible to divide the transition countries into different classes according to the regions in which they are located or according to the blocs that they have left. The common feature of these countries is that they were ruled with a socialist ideology before the transition. Generally, the transition countries are spread on a wide area. It is possible to group these countries as countries located in Eastern and Central Europe, countries that have joined the EU, and countries located in the former USSR and East Asia.

Table 1. Grouping of Transition Economies

\begin{tabular}{|c|c|c|c|c|}
\hline \multirow{2}{*}{$\begin{array}{l}\text { Countries Located In } \\
\text { Eastern Europe }\end{array}$} & \multicolumn{2}{|c|}{ Countries That Have Joined the EU } & \multirow{2}{*}{$\begin{array}{c}\text { Former USSR } \\
\text { countries }\end{array}$} & \multirow{2}{*}{$\begin{array}{c}\text { Countries } \\
\text { Located In East } \\
\text { Asia }\end{array}$} \\
\hline & $\begin{array}{l}\text { Eastern and Central } \\
\text { European countries }\end{array}$ & Baltic States & & \\
\hline Albania & Bulgaria & Estonia & Azerbaijan & China \\
\hline Bosnia and Herzegovina & Romania & Latvia & Armenia & Cambodia \\
\hline North Macedonia & Poland & Lithuania & Belarus & Vietnam \\
\hline Serbia & Hungary & & Georgia & Republic Of Laos \\
\hline Montenegro & Croatia & & Kazakhstan & \\
\hline \multirow[t]{7}{*}{ Kosovo } & Czech Republic & & Kyrgyzstan & \\
\hline & Slovakia & & Moldovan & \\
\hline & Slovenia & & Uzbekistan & \\
\hline & & & Russian Federation & \\
\hline & & & Tajikistan & \\
\hline & & & Turkmenistan & \\
\hline & & & Ukraine & \\
\hline
\end{tabular}

\subsection{Transition to Market Economy}

In the early years of the transition to a market economy, there was no background and theoretical framework regarding what the transition would be like. The first study on this subject was conducted for Latin American countries. The analysis, conducted by international organizations based in Washington was made with the intent of presenting it to the scientist. This work is dubbed as the "Washington Consensus" and was prepared by John Williamson in 1989. This consensus has been a guide for transition countries (Jantsan, 2013). But the Washington Consensus, due to its uniformity did not have the same effect on all transition countries since they have different economic structures. Transition countries had the same economic structure before the system disintegrated. After the dissolution of the former system, the transition countries encountered a different economic structure. For the underground and over ground resources of every transition country was not shared equally. In 
the beginning years of the transition to a market economy, different economic results began to occur in the transition countries.

It is believed that the transition to a market economy occurs by two methods. These are shock therapy and gradual transition methods. Some economists argue that the transition to a market economy, as in Poland, should be based on shock-therapy. Some economists, on the other hand, argue that the transition should be gradual, as in Hungary. In both ways, countries have faced economic shocks during the transition process (Çokünlü, 2007) some these shocks experienced during the transition can be listed as follows;

- There have been declines in production with the release of prices of goods and services.

- Transition countries have lost their economic performance.

- There have been social and economic crises within the country.

- Problems have multiplied in macroeconomic indicators.

According to Aksel, (Aksel, 2019) a number of transition methods were applied in the early stages of the transition process to a free market economy. Some of these methods are expressed as follows.

First, the prices of goods and services are to be freely determined in the market and released from the control of the state. Also, the establishment of the international market and economic relations by way of removing the foreign trade barriers.

Secondly, it serves to ensure the stability of the market. Prices were liberalized with the ensuring of macroeconomic stability. The liberalization of prices, naturally, has led to competition and increased demand. Demand increases have led to excessive inflation. As a result, this mandated the implementation of strict fiscal and monetary policies.

Third is the restructuring of the market and the privatization of state-controlled enterprises.

Fourth is a redefinition of the functions of the state in the economic structure. And the implementation of legal and institutional reforms.

\section{REFORMS IN TRANSITION COUNTRIES}

It is planned that the transition reforms to a free-market economy will be implemented in the social and economic areas in the first place. In transition economics studies what is mainly discussed were economic reforms. According to Jantsn (2013), the reforms that should be implemented in the first place in transition countries are listed as follows:

- Budget deficits should be minimal and they should be funded without resorting to inflation tax.

- Public spending should not be made in areas with low economic earnings. The spending, instead, should be made in areas such as health, education and infrastructure which are areas with high economic earnings and improve the potential income distribution. 
- Tax rates should be reduced and the tax base should be expanded.

- Interest rates should be set freely by the market.

- Export should be supported and encouraged.

- Quantity restrictions on foreign trade should be converted to tariffs.

- Legal and bureaucratic barriers that prevent foreign direct investment should be removed.

- Public enterprises should be privatized.

- Regulations restricting competition, which prevent the entry of new firms, should be removed.

- It must protect the property right of the legal environment without much cost.

11 transition countries, which are close to developed European countries, completed the reforms in a short time. They became members of the European Union and other important organizations. In a short time, they adapted to the new economic system which is the market economy. The effects of the reforms were reflected in the macroeconomic structure. This is clearly seen in Tables 2, 3 and 4. Transitional reforms in the former USSR and South East European countries are progressing slowly. The slow progress of reforms is evident in macroeconomic indicators.

The process of implementing the transition reform to a free-market economy continues in the former USSR and some Southeast European countries. It is not possible to make a final assessment of the transition results. But from the beginning of the transition process to the present day, the economic and social structure of many transition countries has changed. The fact that thirty years have passed from the beginning of the process makes one think that this can be considered a short time for economic and social transformation. It would be correct to examine the results of the transition process over a longer period of time. Academic analysis and studies conducted today is not going to fully reflect the truth. Change in transition countries varies according to the countries' implementation of reforms. The reforms have had a shock effect in "transition countries" in the first place. As time progressed, reforms became directionally influencing. Different results arise when the last thirty years are divided into tenyear periods. The situation happened in the same manner regarding the subjects of unemployment, inflation and per capita income distribution, which we have reviewed.

\section{EFFECTS OF REFORMS ON INFLATION, UNEMPLOYMENT AND NATIONAL INCOME PER CAPITA}

After the collapse of the socialist system, inflation and unemployment in transition countries were the main problems. With the introduction of transitional reforms, supply and demand relations began to experience shocks. These shocks led to increases in price, unemployment and income distribution. The concepts of inflation and unemployment which are not common in the socialist system emerged with the transition to a market economy. In the early years of the transition, the transition countries faced high inflation and unemployment problems. In the beginning, the main reason for the phenomenon of inflation was due to the lack of production of goods and services. Another reason was that the price mechanism was insufficient and resources were not used effectively. 
Faced with high inflation and unemployment rates in the early stages of the transition, a number of countries were able to these problems by meticulously implementing transition reforms. After the 2000s, inflation and unemployment rates in all Eastern European transition countries except Romania declined to single digits. Due to the implementation of the reforms, economic problems still remain in the republics of the Caucasus and Central Asia.

\subsection{The Problem of Inflation}

The Socialist "People's Republic"s in Europe did not interfere with the anti-socialist propaganda initiated by Western states. As a result, socialist powers fell from power one by one. The USSR, which established political and commercial union organizations, was shaken economically. Inflation, which was not present in the Soviet Union era, arose with the transition to a free market economy. Inflation in transition countries soon became a problem. The free-market basing of prices regarding goods and services in the early years of the transition and the rapid increase in prices for basic food goods made the basic food needs of the people difficult (Wikipedia, 2021).

As seen as Table 2, the Socialist "People's Republic"s in the Eastern Europe have experienced three-digit inflation rates during 1991. It was not possible to reach "healthy" figures due to the change of economy in the ex-USSR countries. Asian transition countries, on the other hand, have remained at fairly low levels of inflation due to their adoption of a socialist market economy in 1979 (Bulut, 2017). When the economies of transition countries are examined, it is seen that the successful results in implementing transition reforms have an effect on inflation. All European Union members and Baltic countries experienced the same declines. The same situation has been observed in Tables 2 and 3, with some exceptions.

Especially after the 2000s, the majority of the former socialist countries in Europe have completed transitional reforms. These countries have solved their social and economic problems. In a short time, they became members of many important organizations, especially the EU and NATO.

Table 2. Inflation Rates of Some Select Transition Countries Between 1991 And 2019 (In \%)

\begin{tabular}{|c|c|c|c|c|c|c|c|c|c|c|c|}
\hline $\begin{array}{l}\text { Transition } \\
\text { countries }\end{array}$ & $\bar{\sigma}$ & ळิ & \%̆ & $\hat{\sigma}$ & ฮิ̊ & ஜ̊ํำ & 을 & 象 & 를 & $\stackrel{\infty}{\stackrel{\sim}{*}}$ & ํํำ \\
\hline Bulgaria & 333,45 & 72,88 & 62,06 & 1058,4 & 5,81 & 5,04 & 2,44 & $-0,11$ & 2,06 & 2,81 & 3,10 \\
\hline Romania & 230,62 & 255,17 & 32,24 & 154,76 & 22,54 & 9,02 & 6,09 & $-0,59$ & 1,34 & 4,63 & _- \\
\hline Slovakia & - & 23,29 & 9,84 & 6,14 & 3,13 & 2,71 & 0,96 & $-0,33$ & 1,31 & 2,51 & - \\
\hline Croatia & 122,22 & 1,50 & 3,95 & 4,17 & 1,67 & 3,33 & 1,03 & $-0,46$ & 1,13 & 1,50 & 0,77 \\
\hline Slovenia & 114,83 & 31,76 & 13,46 & 8,36 & 7,48 & 2,45 & 1,80 & $-0,53$ & 1,43 & 1,74 & 1,63 \\
\hline Lithuania & - & 410,45 & 39,65 & 8,88 & 0,28 & 2,64 & 1,32 & $-0,88$ & 3,72 & 2,70 & 2,34 \\
\hline Russia & _ & 874,25 & 197,41 & 14,76 & 15,79 & 12,69 & 6,85 & 15,53 & 3,68 & 2,88 & 4,47 \\
\hline
\end{tabular}




\begin{tabular}{|l|c|c|c|c|c|c|c|c|c|c|c|}
\hline Kazakhstan & - & - & 176,16 & 17,41 & 5,84 & 7,58 & 7,40 & 6,68 & 7,44 & - & - \\
\hline China & 3,56 & 14,61 & 16,79 & 2,79 & $-0,73$ & 1,78 & 3,18 & 1,44 & 1,59 & 2,08 & 2,89 \\
\hline Laos Cum. & 13,44 & 6,27 & 19,59 & 27,51 & 10,63 & 7,17 & 5,98 & 1,28 & 0,83 & 2,04 & - \\
\hline
\end{tabular}

Source: IMF (https://www.imf.org/external/Pubs/FT/irb/2000/eng/03/INDEX.HTM) and data.worldbank.org (accesse on the date of 20.12.2020)

In Table 3, the average inflation rates of the countries of the grouped transition economies are given. During the transition period to a market economy, the transition countries have seen with high inflation rates. The implementation of reforms when transiting to a free-market economy has had an impact on inflation. After the implementation of the reforms, inflation rates have been reduced significantly. Thanks to the drop-in inflation rates the economies of many countries started to grow steadily.

Table 3. Average Inflation Rates of Transition Countries by Country Groups Between 1991 and 2019 (in \%)

\begin{tabular}{|c|c|c|c|c|c|c|c|c|c|c|c|}
\hline Transition Countries & $\bar{g}$ & ğ & $\stackrel{0}{g}$ & s & डิ๊ & 今ั & ปิ่ & in & ثิ & 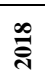 & ते \\
\hline $\begin{array}{l}\text { Eastern European } \\
\text { Countries }\end{array}$ & ' & $\begin{array}{l}0 . \\
\infty \\
\infty\end{array}$ & 占 & $\stackrel{m}{2}$ & $\stackrel{\circ}{\varrho}$ & $\stackrel{+}{+}$ & $\vec{i}$ & $?$ & $\stackrel{i}{i}$ & $\cong$ & $\stackrel{ \pm}{=}$ \\
\hline $\begin{array}{l}\text { Eastern and Central } \\
\text { European }(\mathrm{EU}) \text { countries }\end{array}$ & 童 & हे & $\underset{n}{4}$ & $\stackrel{\circ}{i}$ & ş & $\stackrel{\infty}{\infty}^{\infty}$ & $\hat{i}$ & mi & $\stackrel{\infty}{-}$ & in & i \\
\hline Baltic States & ' & ڤે & $\vec{m}$ & m. & $=$ & 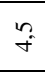 & $=$ & t+ & $\stackrel{m}{m}$ & ते & $a_{i}$ \\
\hline Former USSR countries & ' & $\begin{array}{l}0 \\
\dot{0} \\
i \\
i\end{array}$ & : & $\stackrel{0}{\infty}$ & $\stackrel{n}{\varrho}$ & $\bar{a}$ & $\stackrel{r}{r}$ & $\stackrel{\text { I }}{4}$ & $\stackrel{?}{?}$ & $F$ & $\infty_{\infty}^{\infty}$ \\
\hline East Asian Countries & $n_{\infty}^{n}$ & $\stackrel{t}{\subseteq}$ & $\stackrel{\partial}{=}$ & $\stackrel{\Omega}{t}$ & $\stackrel{\sim}{f}$ & in & $n$ & $\cong$ & i & n & $\underset{i}{\infty}$ \\
\hline
\end{tabular}

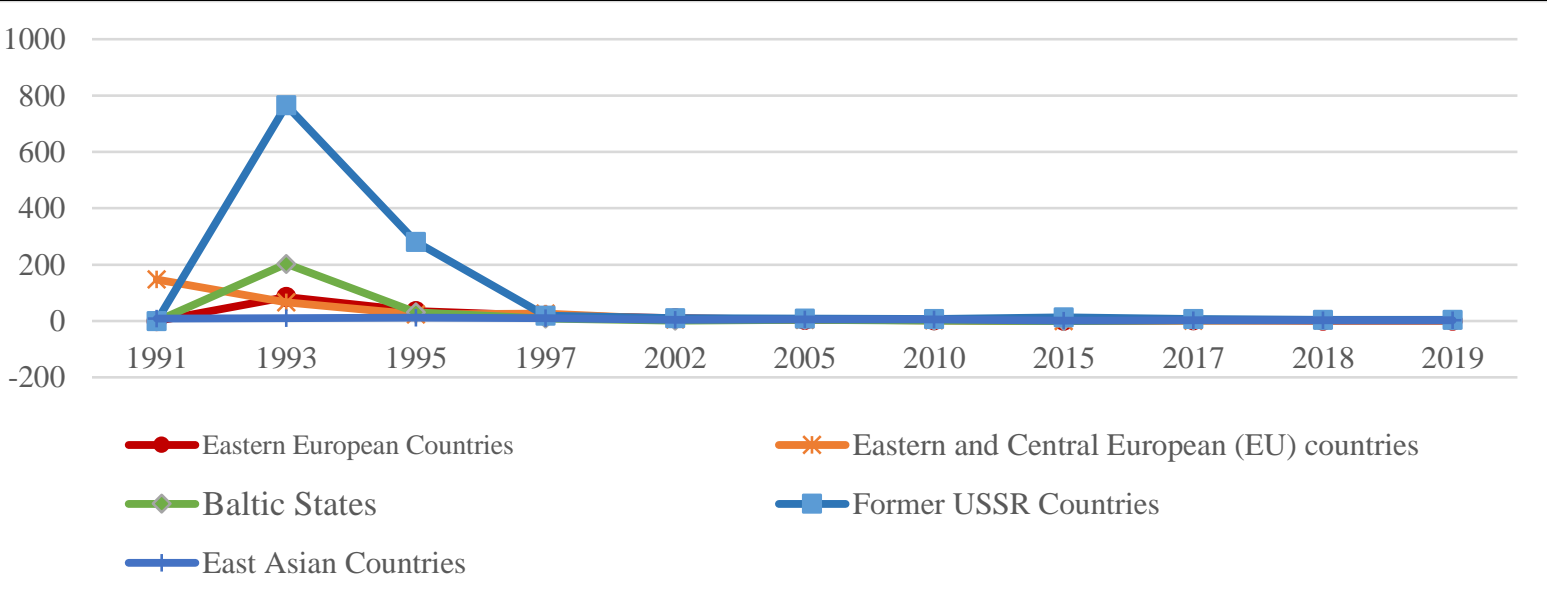

Source: Retrieved from data.worldbank.org

\subsection{The Problem of Unemployment}

During the socialist system, there was no such problem as unemployment in the countries that made up the former Eastern Bloc, Europe and the Soviet Union. During the periods when the socialist system was implemented, unemployment rates were around 1-2\%. As a result of the implementation of the system, those who were unemployed were employed in governmental institutions and organizations. 
Unemployment has occurred due to the lack of a system which was caused by the collapse of the socialist system. Socialist countries, which are the fairest in terms of income distribution, have suddenly become the most unfair countries due to the collapse. In countries subject to the system, many disgraceful crimes were committed due to unemployment. The psychological and moral structure of the society was decorated. Increases were seen in nervous ailments and suicides. Because of unemployment, many people became homeless, unemployed, or they were even forced to migrate legally and illegally to other countries. The Gini Coefficient in the former Eastern Bloc countries. had risen from 0.20 to 0.50 in the first years of the transition.

Table 4. Income Inequality Before and After Transition Period, Gini Coefficient

\begin{tabular}{|l|c|c|c|}
\hline Country Groups & $\mathbf{1 9 8 7 - 8 9}$ & $\mathbf{1 9 9 3}$ & $\mathbf{2 0 0 3}$ \\
\hline Central and Eastern Europe & 0,25 & 0,35 & 0,30 \\
\hline Ex-USSR & 0,26 & 0,45 & 0,43 \\
\hline Median of All Transition Countries & 0,26 & 0,40 & 0,36 \\
\hline
\end{tabular}

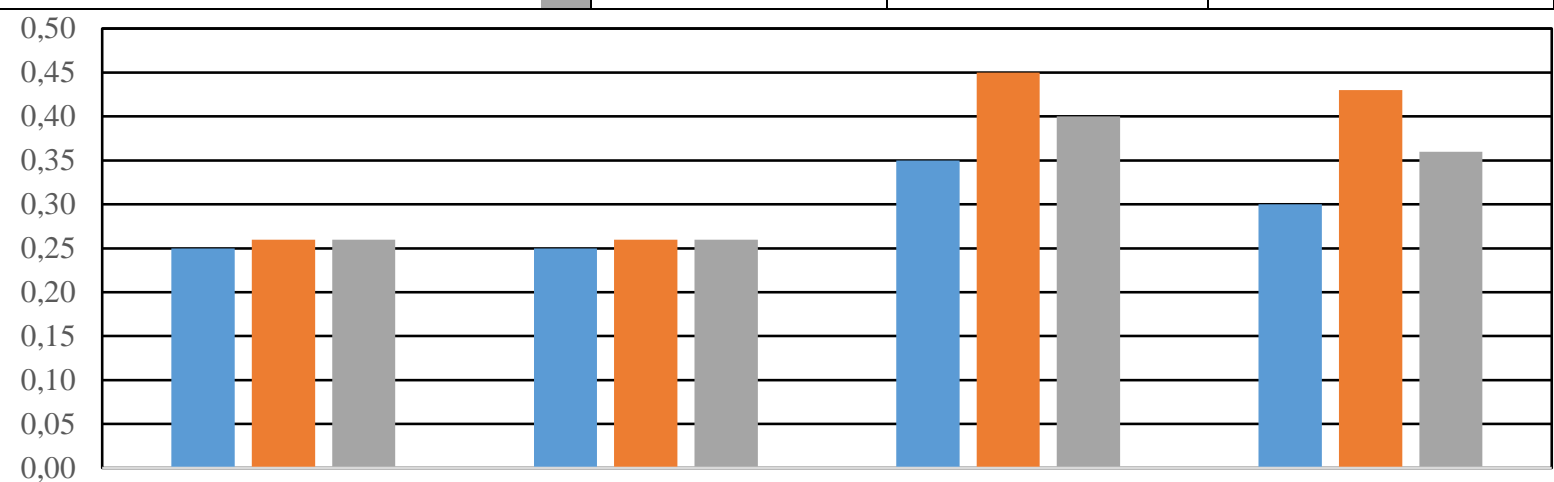

1987

1989

1993

2003

Source: Retrieved from data.worldbank.org

During the first years of transition, a lot of Eastern Bloc citizens were forced to migrate to foreign countries in order to work. Citizens of these countries who were characterized as cheap labor, were seen as an attraction by developed countries. As can be seen in Table 5, the citizens of transition countries near the EU did not emigrate to another country in order to work, which led to an increase in unemployment rates. However, the citizens of the ex-USSR countries have illegally migrated to foreign countries, making the unemployment rates seem smaller. The unemployment rate continued to be constant in countries such as Russia, where there were no migrations of workers. Only during the crisis years did the unemployment rate increase in the Russian Federation.

Table 5. Unemployment Rates of Some Select Transition Countries Between 1991 and 2019 (In \%)

\begin{tabular}{|l|c|c|c|c|c|c|c|c|c|c|c|}
\hline $\begin{array}{l}\text { Transition } \\
\text { Countries }\end{array}$ & $\mathbf{1 9 9 1}$ & $\mathbf{1 9 9 3}$ & $\mathbf{1 9 9 5}$ & $\mathbf{1 9 9 7}$ & $\mathbf{2 0 0 2}$ & $\mathbf{2 0 0 5}$ & $\mathbf{2 0 1 0}$ & $\mathbf{2 0 1 5}$ & $\mathbf{2 0 1 7}$ & $\mathbf{2 0 1 8}$ & $\mathbf{2 0 1 9}$ \\
\hline Bulgaria & 12,18 & 13,03 & 13,33 & 13.7 & 18.10 & 10,08 & 10.27 & 9,14 & 6,16 & 5.26 & 4,81 \\
\hline Romania & 8,18 & 8,4 & 8,01 & 5.51 & 8,11 & 7.17 & 6.95 & 6,81 & 4,92 & 4,29 & 4.15 \\
\hline Slovakia & 11.68 & 12.2 & 13,10 & 11,89 & 18,72 & 16,25 & 14,37 & 11,48 & 8,13 & 6,75 & 6,36 \\
\hline Croatia & 11.14 & 10.88 & 10.11 & 9.71 & 15.05 & 12.59 & 11.62 & 16.17 & 11.20 & 8.85 & 7.76 \\
\hline Slovenia & 7.08 & 8.51 & 7.15 & 6.64 & 5.92 & 6.50 & 7.23 & 8.96 & 6.56 & 5.51 & 5.50 \\
\hline Lithuania & 1.10 & 13.8 & 17.54 & 14.13 & 13.00 & 8.32 & 17.81 & 9.12 & 7.07 & 6 & 6.63 \\
\hline
\end{tabular}




\begin{tabular}{|c|c|c|c|c|c|c|c|c|c|c|c|}
\hline Russia & 5.07 & 5.88 & 9.44 & 11.81 & 7.87 & 7.12 & 7.36 & 5.57 & 5.21 & 4.74 & 4.54 \\
\hline Kazakhstan & 0.9 & 1.11 & 10.98 & 13.01 & 9.33 & 8.13 & 5.77 & 4.93 & 4.9 & 4.88 & 5.42 \\
\hline China & 2.40 & 2.70 & 3.00 & 3.20 & 4.20 & 4.50 & 4.50 & 4.60 & 4.40 & 4.41 & 4.42 \\
\hline Laos Cum. & 2.22 & 2.47 & 2.6 & 2.30 & 2.84 & 1.35 & 0.70 & 0.68 & 0.61 & 0.61 & 0.57 \\
\hline
\end{tabular}

Source: IMF (https://www.imf.org/external/Pubs/FT/irb/2000/eng/03/INDEX.HTM) and data.worldbank.org (accesse on the date of 20.12.2020)

In Table 6, the average unemployment rates of the countries of the grouped transition economies can be seen. Unemployment rates in Eastern European countries have always been at high levels, as seen. Failure to fully implement the reforms in question has had a major impact on unemployment. When compared to eastern European countries and Baltic countries transitioning to the EU, vast differences can be observed between these countries. In the former USSR countries, as well, it was impossible to obtain objective data. East Asian countries, on the other hand, have faced constant unemployment since 1979 since they did not embrace the socialist market economy.

Table 6. Average Unemployment Rates of Transition Countries by Country Groups Between 1991 and 2019 (in \%)

\begin{tabular}{|c|c|c|c|c|c|c|c|c|c|c|c|}
\hline Transition Countries & 1991 & 1993 & 1995 & 1997 & 2002 & 2005 & 2010 & 2015 & 2017 & 2018 & 2019 \\
\hline Eastern European Countries & 22,07 & 23,18 & 23,6 & 24,2 & 24,4 & 27,15 & 22,45 & 21,19 & 17,23 & 17,1 & 17,20 \\
\hline $\begin{array}{l}\text { Eastern and Central European } \\
\text { (EU) countries }\end{array}$ & 9,41 & 10,43 & 9,90 & 9,0 & 12,30 & 10,68 & 9,81 & 8,99 & 6,11 & 5,05 & 4,72 \\
\hline Baltic States & 1,80 & 12,3 & 15,40 & 13,13 & 12,3 & 8,79 & 18,00 & 8,39 & 7,18 & 6,50 & 6,91 \\
\hline Former USSR countries & 1,81 & 4,37 & 8,55 & 11,12 & 10,50 & 8,79 & 8,87 & 7,87 & 7,63 & 7,69 & 7,82 \\
\hline East Asian Countries & 2,20 & 2,40 & 3,00 & 2,70 & 2,70 & 2,40 & 1,90 & 2,10 & 2,00 & 1,99 & 1,98 \\
\hline
\end{tabular}

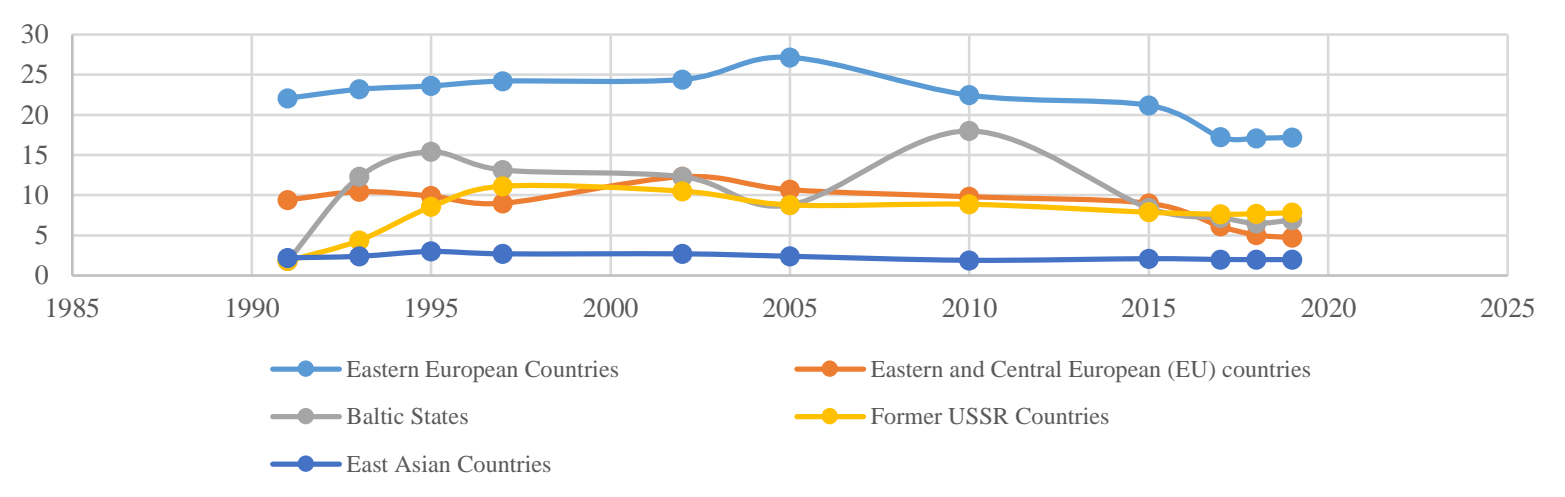

Source: data.worldbank.org

\subsection{Impact of Reforms on the National Income Per Capita}

As the reforms began to be implemented, increases in national income per capita began to occur. When we examine the 27 -years data country by country we see that increases multiplying by ten or thirty do occur. When we look at the group averages of the countries, there is a 10 -fold increase even in the most backward transition country compared to the first years of the transition.

Table 7. National Income Data Per Capita of Some Selected Transition Countries Between 1991 And 2019 (Us Dollars)

\begin{tabular}{|l|l|l|l|l|l|l|l|l|l|l|}
\hline $\begin{array}{l}\text { Transition } \\
\text { countries }\end{array}$ & 1991 & 1993 & 1995 & 1997 & 2002 & 2005 & 2010 & 2015 & 2017 & 2018 \\
\hline
\end{tabular}




\begin{tabular}{|l|c|c|c|c|c|c|c|c|c|c|}
\hline Bulgaria & 1267 & 1278 & 2244 & 1348 & 2076 & 3869 & 6843 & 6993 & 8228 & 9272 \\
\hline Romania & 1260 & 1158 & 1650 & 1577 & 2119 & 4617 & 8209 & 8977 & 10807 & 12301 \\
\hline Slovakia & 2691 & 3102 & 4819 & 5146 & 6533 & 11685 & 16727 & 16309 & 17510 & 19442 \\
\hline Croatia & - & - & 4852 & 5260 & 6233 & 10530 & 13923 & 11782 & 13412 & 14909 \\
\hline Slovenia & 6633 & 6656 & 10730 & 10454 & 11777 & 18098 & 23509 & 20881 & 23442 & 26123 \\
\hline Lithuania & - & - & 2168 & 2830 & 4146 & 7863 & 11953 & 14249 & 16840 & 19153 \\
\hline Russia & 3485 & 2929 & 2665 & 2737 & 2377 & 5323 & 10674 & 9313 & 10750 & 11288 \\
\hline Kazakhstan & 1512 & 1433 & 1288 & 1445 & 1658 & 3771 & 9070 & 10510 & 9247 & 9812 \\
\hline China & 333 & 377 & 609 & 781 & 1148 & 1753 & 4550 & 8033 & 8759 & 9770 \\
\hline Laos & 234 & 287 & 363 & 345 & 320 & 475 & 1140 & 2134 & 2423 & 2542 \\
\hline
\end{tabular}

Source: https://www.imf.org/external/Pubs/FT/irb/2000/eng/03/INDEX.HTM

Transition countries have experienced significant changes in their macroeconomic structures over the past 30 years. During the collapse of the socialist system in the Baltic countries, the average national income per person was 2000 US dollars, while in 30 years it exceeded 20 thousand dollars. Baltic countries are followed by Eastern European countries that are members of the European Union. East Asian countries have the lowest per capita income.

Table 8. Average Data of Per Capita of Some Selected Transition Countries Between 1991 and 2019 (US dollars)

\begin{tabular}{|l|c|c|c|c|c|c|c|c|c|c|}
\hline Transition countries & $\mathbf{1 9 9 1}$ & $\mathbf{1 9 9 3}$ & $\mathbf{1 9 9 5}$ & $\mathbf{1 9 9 7}$ & $\mathbf{2 0 0 2}$ & $\mathbf{2 0 0 5}$ & $\mathbf{2 0 1 0}$ & $\mathbf{2 0 1 5}$ & $\mathbf{2 0 1 7}$ & $\mathbf{2 0 1 8}$ \\
\hline Eastern European Countries & 1407 & 860 & 1448 & 1710 & 1804 & 3039 & 4829 & 4865 & 5560 & 6301 \\
\hline $\begin{array}{l}\text { Eastern and Central European } \\
\text { EU) countries }\end{array}$ & 2902 & 3136 & 4782 & 4812 & 6078 & 10171 & 14341 & 13485 & 15261 & 17088 \\
\hline Baltic States & - & 2681 & 2540 & 3061 & 4538 & 8607 & 12694 & 15166 & 17575 & 20093 \\
\hline Former USSR Countries & 1333 & 1050 & 868 & 932 & 981 & 2030 & 4542 & 4833 & 4911 & 5153 \\
\hline East Asian Countries & 235 & 275 & 393 & 445 & 559 & 847 & 1948 & 3354 & 3733 & 4097 \\
\hline
\end{tabular}

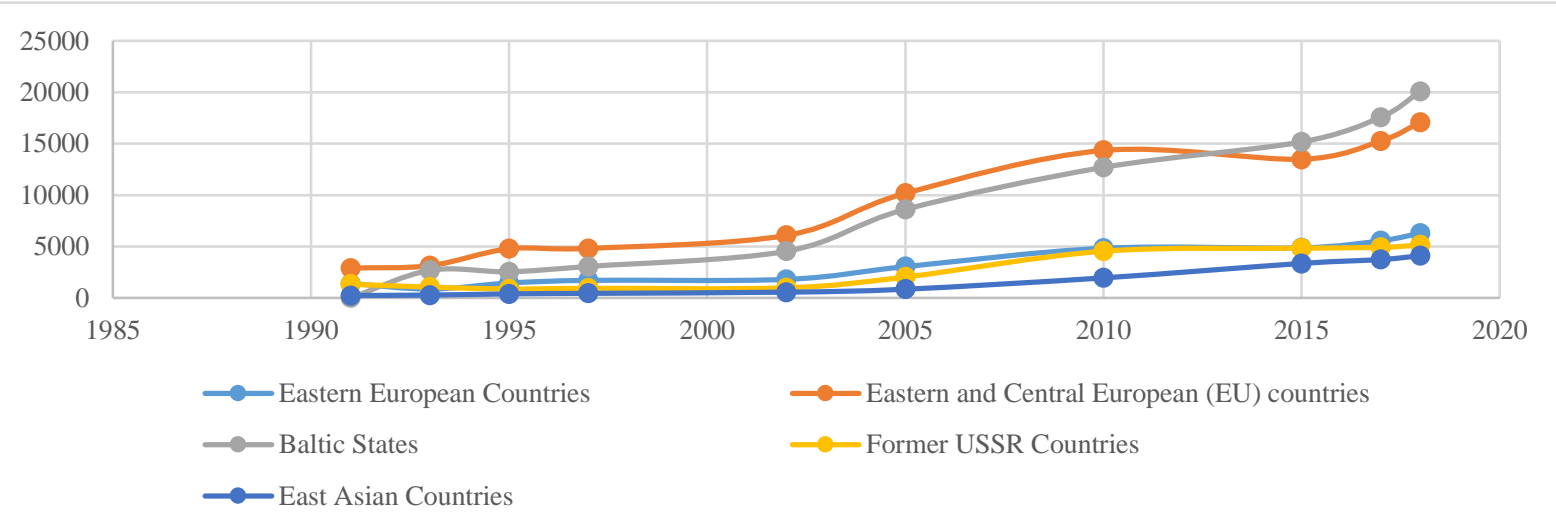

Source: data.worldbank.org

\section{CONCLUSION AND DISCUSSION}

In this study, inflation, unemployment rates and averages of national income per capita in transition countries and Eastern European countries, Eastern and Central European countries, Baltic countries, former USSR countries and East Asian countries were discussed as data. Comparative 
inferences were made based on the inflation, unemployment and national income per capita averages between 1991 and 2019 of some select transition countries.

According to the findings of the study, the implementation of transition reforms to a market economy has a direct impact on inflation, unemployment and national income per capita. It is inevitable that transitional reforms are also going to have an impact on other macroeconomic indicators.

In this study, the problems of inflation, unemployment and income distribution in the transition process of Eastern Bloc countries to market economy were discussed with the examples of selected regional countries. Other macroeconomic problems can be discussed in another study.

With the end of the nearly 70-year central planning system, the world economy has begun to reshape itself. With the transition of countries governed by the socialist central system to a free market economy, the study fields of "transition countries" and "transition economies" entered the literature. It is accepted by economists that there is no difference between the concept of transition countries and the concept of transition economies.

Today, there are a total of 33 countries that are considered transition economies or countries. Of these countries, those in Central and Eastern Europe and the Baltic countries remained within the socialist system for about 40 to 50 years. Countries located in the Caucasus and Central Asia have remained within the system for 70 years. As a matter of fact, countries that remained in the socialist system for a lesser amount of time have completed transition reforms to a market economy more quickly. In countries that have remained for a long time, however, transition reforms are still not completed. Countries in Asia are implementing different transitional reforms. Some Asian countries are even labeled as "socialist market countries".

The transition from central planning to a free-market economy is progressing in a very complicated way. In the first phase of the transition process, there were problems in the macroeconomic structures of all socialist countries. During the transition process, special transition strategies and policies were necessitated to prevent countries from facing further social and economic problems.

The study dealt with limited macroeconomic problems and some select countries. Given the general nature of the problems and all of the transition countries, it is likely that there will be different consequences. For example, we can talk about the dependence of countries closer to Europe on developed European countries, the majority of countries of the former USSR on the Russian Federation, and transition countries located in Asia on the People's Republic of China. There are similarities in data and rates in macroeconomic indicators.

In the first years of the transition to a market economy, liberalization in prices led to a period of rapid inflation. In 1991-1993, some transition countries experienced high and hyperinflation phenomena 
with monthly inflation rates of $30 \%$. The increase in prices and wages for goods and services was not at the same rate. Indirectly, labor and brain drain to developed countries has accelerated.

After 1995, due to the increase in the number of foreign investors and the increase loans from the IMF, inflation rates began to decline. The Asian financial crisis of 1997 negatively affected the economies of the Russian Federation and neighboring countries.

Transition reforms and programs implemented during the transition to a free-market economy have had a negative impact on the economies of transition countries in the first place. As time progressed, problems in the economies of transition countries disappeared with the implementation of reforms. Eastern European transition countries soon solved the problems inflation, unemployment, national income per capita and other macroeconomic problems.

\section{REFERENCES}

Aksel, E. (2019), Piyasa Ekonomisine Geçiş süreci Ve Sonrasında Türkiye - Rusya Federasyonu Ekonomik İlişkiler, Burdur Mehmet Akif Ersoy Üniversitesi (MAKÜ), Sosyal Bilimler Enstitüsü İktisat Anabilim Dalı, Yayımlanmamış Yüksek Lisans Tezi, 2019, Burdur.

Bağırzade, E. R. (2011), Dönüşüm Ekonomileri, Lecture Notes of [Transformation Economies], Turkish World Faculty of Business Administration, Bakü, 2011

Bulut, R. (2020) Geçiş ekonomisi ülkelerde reformlarin makroekonomik göstergelere etkisi, Journal Social Research and Behavioral Sciences, 6(12), 235-245,

Bulut, R., (2017), Eski SSCB ülkeleri (sosyal ve ekonomik yapıları üzerine bir araştırma), Fakülte Kitabevi, Isparta.

Bulut, R. (2014), SSCB'nin dağılmasi ve Rusya Federasyonu'nda serbest piyasaya geçiş. Mehmet Akif Ersoy Üniversitesi İktisadi ve İdari Bilimler Fakültesi Dergisi, 1(2), 7-19

Bulut, R., (2019), Transition economies and countries. Ayrintr, 6(70), 57-63

Çokünlü, E. G. (2007), Geçiş Ekonomilerinde Makroekonomik İstikrar Sorunları: Rusya Örneği, T.C. Uludağ Üniversitesi, Sosyal Bilimler enstitüsü İktisat Anabilim Dalı, Doktora Tezi

DEIK (2012), Russian Federation Country Bulletin, (2021, January 10)

Ericson, R. (1991), The classical Soviet - Type Economy: nature of the system an dimplications for reform. Journal of Economic Perspectives, 5 (4): 11-27

Falcetti, E., Raiser, M. \& Sanfey, P. (2000). Defying the odds: Initial conditions, reforms and growth in the first decade of transition, Journal of Comparative Economics, 30, 229250.

IMF Research Bulletin - December 2000, (2020, December 10) https://www.imf.org/external/Pubs/FT/irb/2000/eng/03/INDEX.HTM

Işık, A. (2013), Sosyalist ekonomik sistemden piyasa ekonomisine geçişin nedenleri, Yönetim ve Ekonomi Araştırmalart Dergisi, 20, 105-1180 Doi: http://dx.doi.org/10.11611/JMER168]

Jantsan, S. (2013), Geçiş Ekonomilerinde Reform Sürecinin Değerlendirilmesi, Hacettepe Üniversitesi, Sosyal Bilimler Enstitüsü İktisat Anabilim Dalı, Yayımlanmış Yüksek Lisans Tezi, Ankara. 
John Williamson, (2004), The Washington Consensus as Policy Prescription for Development retrieved from https://www.piie.com/publications/papers/williamson0204.pdf

Karış, Ç. ve Özyurt, H. (2015), Geçiş sürecindeki merkezi ve Doğu Avrupa ülkelerinin makroekonomik performansı: Seçilmiş ülke değerlendirmeleri, KTÜ SBE Sosyal Bilimler Dergisi, (9), 39-54

Lavigne, M. (1995), The economics of transition - from socialist economy to market economy. St. Martin's Press, New York

Nikolayevoy, İ. P. (Redaktor), (2001), Teoriya Perehodnoy Ekonomiki: Uçebnoye Posobiye [Theory of Transition Economics: Workbook], Moscow, 2001.

Ölmezoğulları, N. (2012), Ekonomik Sistemler ve Küreselleşen Kapitalizm, Ezgi Yayınevi [Economic Systems and Globalizing Capitalism, Ezgi Publications]

Papava, V. (2005), On the theory of post - communist economic transition to market, International Journal of Social Economics, 32 (1/2, 77 - 97

Radayeva, V. V. \& Buzgalina, A. V. (Redaktor) (1995), Ekonomika Perehodnogo Perioda, [Transition Economics: Workbook], Moscow

Roland, G. (2001). Ten Years After - Transition and Economics. IMF Staff Papers, 48(Special Issue) 29-52

Sakınç, S. (2005), Geçiş Ekonomileri ve Orta Asya Türk Cumhuriyetlerinde ekonomik reformlar, Emek Yayınc1lik, Manisa, 2005.

Turan, G. \& Işık, A. (2007), Devlet sosyalizminden piyasa ekonomisine geçiş, [Transition from State Socialism to the Market Economy], Ekin Kitabevi Yayınları, Bursa

Wikipedia, $\quad$ Enflasyon (2021, January 10) https://tr.wikipedia.org/wiki/Enflasyon\#: :text=Enflasyon\%2C\%20fiyatlar\%20genel $\% 20 \mathrm{~d} \% \mathrm{C} 3 \%$ BCzeyinin $\% 20 \mathrm{~s} \% \mathrm{C} 3 \%$ BCrekli,nazaran\%20artmas\%C4\%B1\%20yani\%2 $0 \% \mathrm{C} 5 \% 9 \mathrm{Fi} \% \mathrm{C} 5 \% 9 \mathrm{Fmesi} \% 20 \mathrm{demektir}$.

World Bank, (2021, January 12) https://data.worldbank.org/countr 